\title{
Climatological variations of total alkalinity and total dissolved inorganic carbon in the Mediterranean Sea surface waters
}

\author{
E. Gemayel ${ }^{1,2,3}$, A. E. R. Hassoun ${ }^{3}$, M. A. Benallal ${ }^{1,2}$, C. Goyet ${ }^{1,2}$, P. Rivaro ${ }^{4}$, M. Abboud-Abi Saab ${ }^{3}$, \\ E. Krasakopoulou ${ }^{5}$, F. Touratier ${ }^{1,2}$, and P. Ziveri ${ }^{6,7}$ \\ ${ }^{1}$ Université de Perpignan Via Domitia, IMAGES_ESPACE-DEV, 52 avenue Paul Alduy, 66860 Perpignan \\ CEDEX 9, France \\ ${ }^{2}$ ESPACE-DEV, UG UA UR UM IRD, Maison de la télédétection, 500 rue Jean-François Breton, 34093 \\ Montpellier CEDEX 5, France \\ ${ }^{3}$ National Council for Scientific Research, National Center for Marines Sciences, P.O. Box \\ 534, Batroun, Lebanon \\ ${ }^{4}$ University of Genoa, Department of Chemistry and Industrial Chemistry, via Dodecaneso 31 , \\ 16146 Genoa, Italy \\ ${ }^{5}$ University of the Aegean, Department of Marine Sciences, University Hill, Mytilene 81100, Greece \\ ${ }^{6}$ Institute of Environmental Science and Technology (ICTA) and Department of Biology (BAVE), Universitat \\ Autònoma de Barcelona ICTA-ICP, Edifici Z, Carrer de les columnes s/n, 08193 Bellaterra, Barcelona, Spain \\ ${ }^{7}$ Catalan Institution for Research and Advanced Studies (ICREA), 08010 Barcelona, Spain
}

Correspondence to: E. Gemayel (elissargemayel@hotmail.com)

Received: 28 June 2015 - Published in Earth Syst. Dynam. Discuss.: 24 August 2015

Revised: 16 November 2015 - Accepted: 1 December 2015 - Published: 15 December 2015

\begin{abstract}
A compilation of data from several cruises between 1998 and 2013 was used to derive polynomial fits that estimate total alkalinity $\left(\mathrm{A}_{\mathrm{T}}\right)$ and total dissolved inorganic carbon $\left(\mathrm{C}_{\mathrm{T}}\right)$ from measurements of salinity and temperature in the Mediterranean Sea surface waters. The optimal equations were chosen based on the 10-fold cross-validation results and revealed that second- and third-order polynomials fit the $\mathrm{A}_{T}$ and $\mathrm{C}_{\mathrm{T}}$ data respectively. The $\mathrm{A}_{\mathrm{T}}$ surface fit yielded a root mean square error (RMSE) of $\pm 10.6 \mu \mathrm{mol} \mathrm{kg}^{-1}$, and salinity and temperature contribute to $96 \%$ of the variability. Furthermore, we present the first annual mean $\mathrm{C}_{\mathrm{T}}$ parameterization for the Mediterranean Sea surface waters with a RMSE of $\pm 14.3 \mu \mathrm{mol} \mathrm{kg}^{-1}$. Excluding the marginal seas of the Adriatic and the Aegean, these equations can be used to estimate $\mathrm{A}_{\mathrm{T}}$ and $\mathrm{C}_{\mathrm{T}}$ in case of the lack of measurements. The identified empirical equations were applied on the $0.25^{\circ}$ climatologies of temperature and salinity, available from the World Ocean Atlas 2013. The 7-year averages (2005-2012) showed that $A_{T}$ and $C_{T}$ have similar patterns with an increasing eastward gradient. The variability is influenced by the inflow of cold Atlantic waters through the Strait of Gibraltar and by the oligotrophic and thermohaline gradient that characterize the Mediterranean Sea. The summer-winter seasonality was also mapped and showed different patterns for $A_{T}$ and $C_{T}$. During the winter, the $\mathrm{A}_{\mathrm{T}}$ and $\mathrm{C}_{\mathrm{T}}$ concentrations were higher in the western than in the eastern basin. The opposite was observed in the summer where the eastern basin was marked by higher $\mathrm{A}_{\mathrm{T}}$ and $\mathrm{C}_{\mathrm{T}}$ concentrations than in winter. The strong evaporation that takes place in this season along with the ultra-oligotrophy of the eastern basin determines the increase of both $\mathrm{A}_{\mathrm{T}}$ and $\mathrm{C}_{\mathrm{T}}$ concentrations.
\end{abstract}




\section{Introduction}

The role of the ocean in mitigating climate change is well known, as it absorbs about $2 \mathrm{Pg} \mathrm{C} \mathrm{yr}^{-1}$ of anthropogenic $\mathrm{CO}_{2}$ (Wanninkhof et al., 2013). Worldwide measurements of surface seawater $\mathrm{CO}_{2}$ properties are being conducted as they are important for advancing our understanding of the carbon cycle and the underlying processes controlling it. For instance, the buffer capacity of the $\mathrm{CO}_{2}$ system varies with temperature, the distribution of total inorganic carbon, and total alkalinity (Omta et al., 2011).

Our understanding of the open-ocean $\mathrm{CO}_{2}$ dynamics has drastically improved over the years (Rödenbeck et al., 2013; Sabine et al., 2004; Takahashi et al., 2009; Watson and Orr, 2003). However, our understanding of marginal seas such as the Mediterranean remains poor due to the limited measurements combined with the enhanced complexity of the landocean interactions. In the Mediterranean Sea, available measurements of the carbonate system are still scarce and only available in specific regions such as the Alboran Sea (CopinMontégut, 1993), the Gibraltar Strait (Santana-Casiano et al., 2002), the DYFAMED (Dynamics of Atmospheric Fluxes in the Mediterranean Sea) time series in the Ligurian Sea (Bégovic and Copin-Montégut, 2002; Copin-Montégut and Bégovic, 2002; Touratier and Goyet, 2009), and the Otranto Strait (Krasakopoulou et al., 2011). Large geographical distribution of $\mathrm{CO}_{2}$ data are often confined to cruises with a short sampling period (Álvarez et al., 2014; Goyet et al., 2015; Rivaro et al., 2010; Schneider et al., 2007; Touratier et al., 2012). Numerical models have provided some insights into the carbon dynamics in the Mediterranean Sea (Cossarini et al., 2015; D'Ortenzio et al., 2008; Louanchi et al., 2009), but it remains important to constrain the system from in situ measurements to validate their output.

The scarcity of the $\mathrm{CO}_{2}$ system measurements in the Mediterranean Sea make it difficult to constrain the $\mathrm{CO}_{2}$ uptake in this landlocked area and also limits our understanding of the magnitude and mechanisms driving the natural variability on the ocean carbon system (Touratier and Goyet, 2009). Empirical modelling has been successfully used to study the marine carbon biogeochemical processes such as the estimation of biologically produced $\mathrm{O}_{2}$ in the mixed layer (Keeling et al., 1993), estimation of global inventories of anthropogenic $\mathrm{CO}_{2}$ (Sabine et al., 2004), and estimation of the $\mathrm{CaCO}_{3}$ cycle (Koeve et al., 2014). Empirical algorithms were also used to relate limited $\mathrm{A}_{\mathrm{T}}$ and $\mathrm{C}_{\mathrm{T}}$ measurements to more widely available physical parameters such as salinity and temperature (Bakker et al., 1999; Ishii et al., 2004; Lee et al., 2006). The $A_{T}$ and $C_{T}$ fields can then be used to calculate $\mathrm{pCO}_{2}$ fields and thus predict the $\mathrm{CO}_{2}$ flux across the air-sea interface (McNeil et al., 2007).

Previous empirical approaches to constrain $\mathrm{A}_{T}$ in the Mediterranean Sea have only covered selected cruises (Schneider et al., 2007; Touratier and Goyet, 2009) or local areas such as the DYFAMED time-series station or the Strait of Gibraltar (Copin-Montégut, 1993; Santana-Casiano et al., 2002). As for $C_{T}$, empirical models have only been applied to data below the mixed layer depth (MLD) following the equation of Goyet and Davis (1997) at the DYFAMED time-series station (Touratier and Goyet, 2009) or using the composite data set from Meteor 51/2 and DYFAMED (Touratier and Goyet, 2011). Lovato and Vichi (2015) also proposed an optimal multiple linear model for $\mathrm{C}_{\mathrm{T}}$ using the Meteor $84 / 3$ full water column data. To the best of our knowledge the reconstruction of $\mathrm{C}_{\mathrm{T}}$ in surface waters has not been yet performed in the Mediterranean Sea. This is probably due to the lack of measurements available for previous studies to capture the more complex interplay of biological, physical and solubility processes that drive $\mathrm{C}_{\mathrm{T}}$ variability in the surface waters.

In this study we have compiled $\mathrm{CO}_{2}$ system measurements from 14 cruises between 1995 and 2013, which allowed us to constrain an improved and new empirical algorithm for $\mathrm{A}_{\mathrm{T}}$ and $\mathrm{C}_{\mathrm{T}}$ in the Mediterranean Sea surface waters. We also evaluated the spatial and seasonal variability of the carbon system in the Mediterranean Sea surface waters by mapping the 2005-2012 annual and seasonal averages of surface $A_{T}$ and $\mathrm{C}_{\mathrm{T}}$ using the $0.25^{\circ}$ climatologies of salinity and temperature from the WOA13.

\section{Methods}

\subsection{Surface $A_{T}$ and $C_{T}$ data in the Mediterranean Sea}

Between 1998 and 2013, there were multiple research cruises sampling the seawater properties throughout the Mediterranean Sea. This includes parameters of the carbonate system, more specifically $\mathrm{A}_{\mathrm{T}}, \mathrm{pH}$, and $\mathrm{C}_{\mathrm{T}}$ and physico-chemical properties of in situ salinity and temperature. In this study we have compiled surface water samples between 0 and $10 \mathrm{~m}$ depth, totaling 490 and 400 measurements for $A_{T}$ and $C_{T}$ respectively (Table 1).

\subsection{Polynomial model for fitting $\mathrm{A}_{\boldsymbol{T}}$ and $\mathrm{C}_{\mathrm{T}}$ data}

Two polynomial equations for fitting $\mathrm{A}_{\mathrm{T}}$ or $\mathrm{C}_{\mathrm{T}}$ from salinity (S) alone or combined with sea surface temperature $(T)$ in the surface waters $(0-10 \mathrm{~m})$ of the Mediterranean Sea were chosen from the results of the 10-fold cross-validation method (Breiman, 1996; Stone, 1974). This type of analysis was previously performed by Lee et al. (2006) for general relationships of $\mathrm{A}_{\mathrm{T}}$ with salinity and temperature. This model validation technique is performed by randomly portioning the data set into 10 equal subsamples. One subsample is used as the validation data and the nine remaining subsamples are used as training data. The cross-validation process is then repeated 10 times, with each of the 10 subsamples used exactly once as the validation data. In this manner, all observations are used both for training and validation, and each observation is used for validation only once. The best fit is chosen by computing the residuals from each regression model and 
Table 1. List of available carbonate system datasets for the Mediterranean Sea.

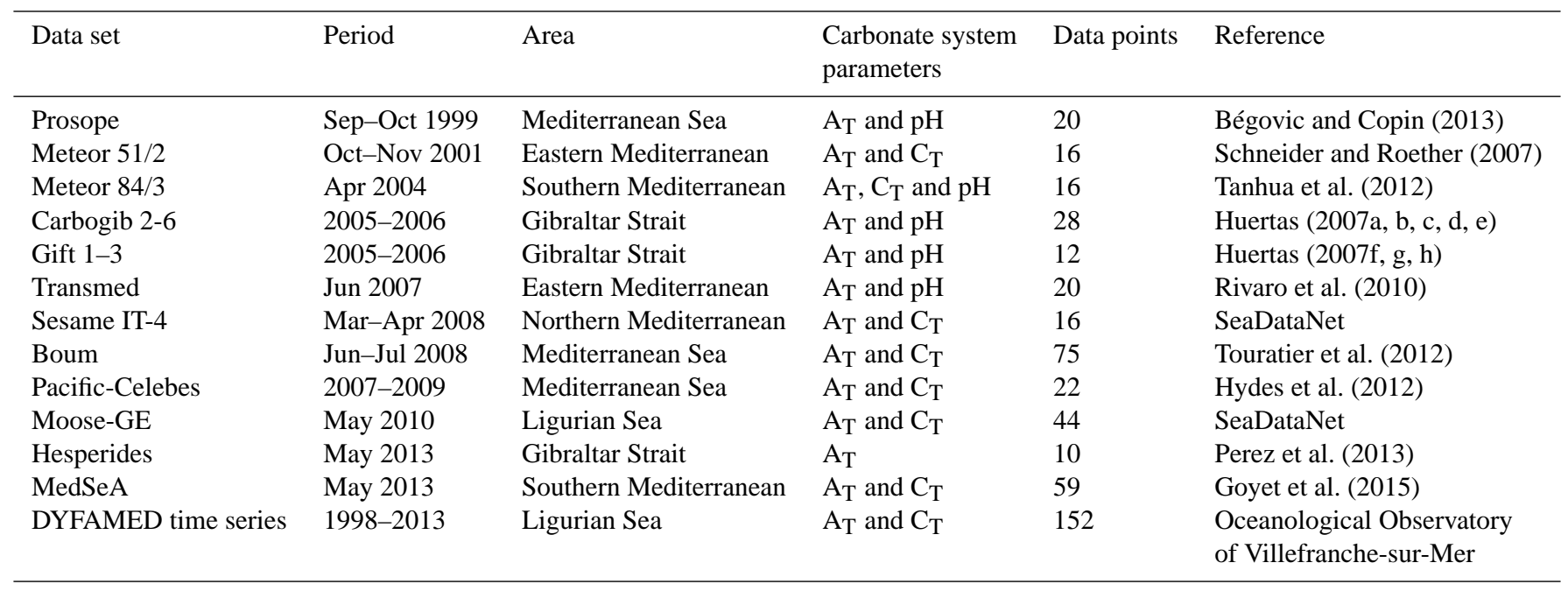

computing independently the performance of the selected optimal polynomial on the remaining subsets.

The analysis was applied for polynomials of order 1-3, and the optimal equation was chosen based on the lowest root mean square error (RMSE) and the highest coefficient of determination $\left(r^{2}\right)$. High-order polynomials (4 and above) were discarded because they can be oscillatory between the data points, leading to a poorer fit to the data.

The data set consists of 490 and 400 data points for $\mathrm{A}_{\mathrm{T}}$ and $\mathrm{C}_{\mathrm{T}}$ respectively (Table 1 ). To ensure the same spatial and temporal coverage of the polynomial fits, the same training data set was retained for both $\mathrm{A}_{\mathrm{T}}$ and $\mathrm{C}_{\mathrm{T}}$. This was performed by selecting stations were both parameters were simultaneously measured, yielding 360 data points (Fig. 1). To validate the general use of the proposed parameterizations we tested the algorithms with measurements which are not included in the fits (validation data set). For $\mathrm{A}_{\mathrm{T}}$, the validation data set consists of 130 data points which are formed from the testing subset of the 10th fold (40 data points) and from cruises where $A_{T}$ was measured without accompanying $C_{T}$ (90 data points). For $\mathrm{C}_{\mathrm{T}}$, the validation data set is the same as the testing subset of the 10th fold (40 data points).

\subsection{Climatological and seasonal mapping of $A_{T}$ and $C_{T}$}

The climatological and seasonal averages of salinity (Zweng et al., 2013) and temperature (Locarnini et al., 2013) in $0.25 \times 0.25^{\circ}$ grid cells were downloaded from the WOA13. The 7-year averages (2005-2012) and the summer-winter seasonality of $\mathrm{A}_{\mathrm{T}}$ and $\mathrm{C}_{\mathrm{T}}$ fields were mapped at $5 \mathrm{~m}$ depth by applying the respective derived algorithms in their appropriate ranges of $\mathrm{S}$ and $T$. The summer seasonality is defined as the average of the months of July, August, and September. The winter seasonality is defined as the average of the months of January, February, and March.

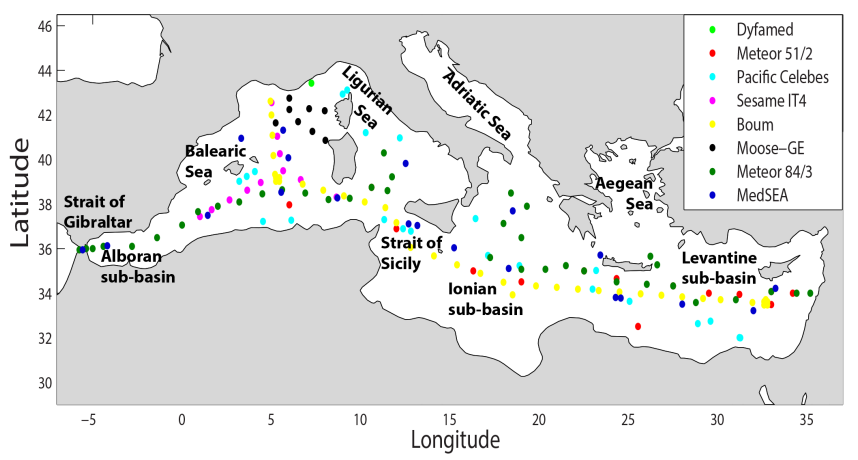

Figure 1. Spatial distribution of data points used to initiate the fits of $\mathrm{A}_{\mathrm{T}}$ and $\mathrm{C}_{\mathrm{T}}$.

\section{Results and discussion}

\subsection{Fitting $A_{T}$ in the Mediterranean Sea surface waters}

In the surface ocean the $\mathrm{A}_{\mathrm{T}}$ variability is controlled by freshwater addition or the effect of evaporation, and salinity contributes to more than $80 \%$ of the $\mathrm{A}_{\mathrm{T}}$ variability (Millero et al., 1998). In the Mediterranean Sea, several studies have shown that the relationship between $\mathrm{A}_{\mathrm{T}}$ and $\mathrm{S}$ is linear (Copin-Montégut, 1993; Copin-Montégut and Bégovic, 2002; Hassoun et al., 2015b; Jiang et al., 2014; Rivaro et al., 2010; Schneider et al., 2007). In other studies, the sea surface temperature $(T)$ has been included as an additional proxy for changes in surface water $\mathrm{A}_{\mathrm{T}}$ related to convective mixing (Lee et al., 2006; Touratier and Goyet, 2011). 
The results of the 10-fold cross-validation analysis revealed that the optimal model for $\mathrm{A}_{\mathrm{T}}$ is a second-order polynomial in which $\mathrm{A}_{\mathrm{T}}$ is fitted to both $\mathrm{S}$ and $T$ (Eq. 1).

$\mathrm{A}_{\mathrm{T}}=2558.4+49.83(S-38.2)-3.89(T-18)$

$-3.12(S-38.2)^{2}-1.06(T-18)^{2}$.

valid for $T>13^{\circ} \mathrm{C}$ and $36.30<\mathrm{S}<39.65 ; n=375 ; r^{2}=0.96$; and RMSE $=10.6 \mu \mathrm{mol} \mathrm{kg}{ }^{-1}$,

A linear relationship between $\mathrm{A}_{\mathrm{T}}$ and $\mathrm{S}$ yields a higher RMSE $\left(14.5 \mu \mathrm{mol} \mathrm{kg}{ }^{-1}\right)$ and a lower $r^{2}(0.91)$ than Eq. (1). In a semi-enclosed basin such as the Mediterranean Sea, the insulation and high evaporation as well as the input of rivers and little precipitation leads to a negative freshwater balance (Rohling et al., 2009). The resulting anti-estuarine thermohaline circulation could explain the contribution of temperature to the $A_{T}$ variability (Touratier and Goyet, 2011).

The residuals of the training data set used to generate the second-order polynomial fit for $\mathrm{A}_{\mathrm{T}}$ are presented in Fig. 2a. Most of the $A_{T}$ residuals (340 out of 375 ) were within a range of $\pm 15 \mu \mathrm{mol} \mathrm{kg}{ }^{-1}(1 \sigma)$. However, 35 residuals were high up to $\pm 30 \mu \mathrm{mol} \mathrm{kg}{ }^{-1}(1 \sigma)$. Applying the $\mathrm{A}_{\mathrm{T}}$ algorithm to the testing data set (Fig. $2 b$ ) yields a mean residual of $0.91 \pm 10.30 \mu \mathrm{mol} \mathrm{kg}^{-1}(1 \sigma)$, and only six data points have residuals higher than $\pm 15 \mu \mathrm{mol} \mathrm{kg}{ }^{-1}(1 \sigma)$. Furthermore, to make sure that the $\mathrm{A}_{\mathrm{T}}$ algorithm does not overfit the data, we tested the difference in means between the RMSE and residuals between the training set compared to the testing set. The results show that for both the RMSE and mean residual, we cannot reject the null hypothesis (that assumes equal means) between the training and validation data sets (Table 2).

The comparison of the RMSE reported by other studies with that of Eq. (1) does not indicate if the parameterization developed here has advanced or not on previous attempts in the Mediterranean Sea. In that order, we independently applied each of the previous equations on the same training data set used to develop Eq. (1) and then computed the RMSE and $r^{2}$ for every one (Table 3). The results show that Eq. (1) has a lower RMSE and a higher $r^{2}$ than all of the parameterizations presented in Table 3. For instance, the general relationship of Lee et al. (2006) applied to the data set of this study yields an RMSE as high as $\pm 40.50 \mu \mathrm{mol} \mathrm{kg}{ }^{-1}$. The RMSE of other studies developed strictly in the Mediterranean Sea varied from \pm 13.81 to $\pm 26.11 \mu \mathrm{mol} \mathrm{kg}-1$ using the equations of Touratier and Goyet (2011) and Schneider et al. (2007) respectively.

By applying directly the previous parameterizations to our training data set, the calculated RMSEs are significantly higher than the ones reported in their respective studies. For instance the reported RMSE in Lee et al. (2006) for subtropical oceanic regions is $\pm 8 \mu \mathrm{mol} \mathrm{kg}{ }^{-1}$ and that of Schneider et al. (2007) for the Meteor $51 / 2$ cruise is $\pm 4.2 \mu \mathrm{mol} \mathrm{kg}{ }^{-1}$. This shows that previous models were constrained by their spatial coverage, time span, and used data sets. In fact the previous equations were calculated in local areas such as the
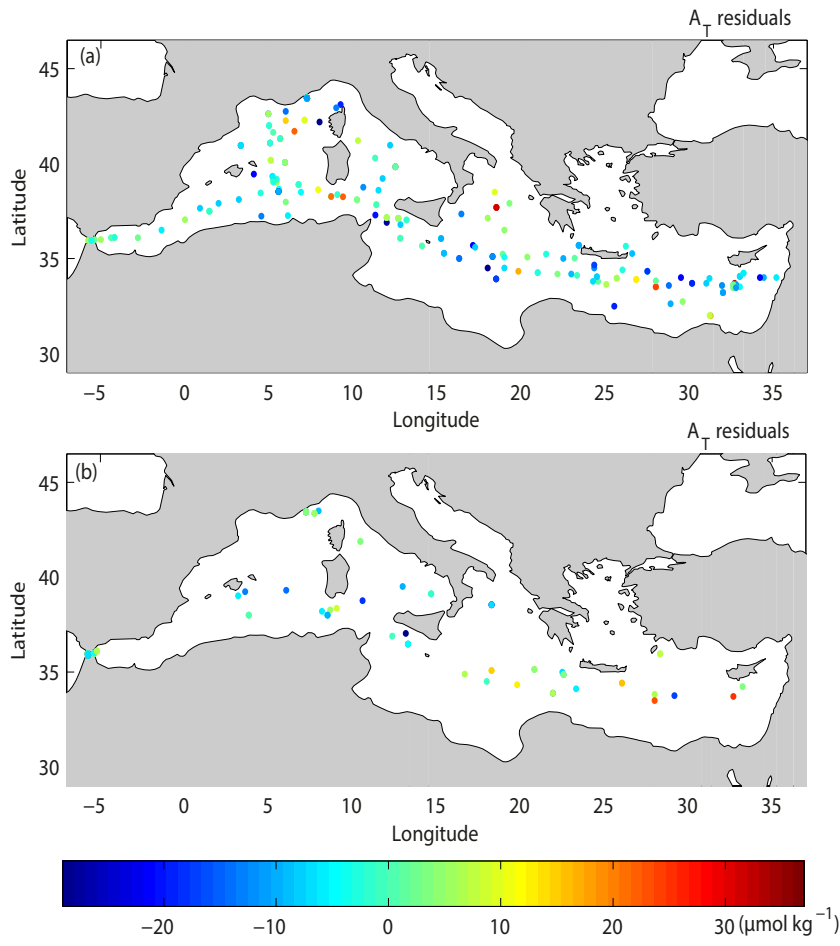

Figure 2. Map of the residuals of the $\mathrm{A}_{\mathrm{T}}$ algorithm (Eq. 1) applied to the (a) training and (b) testing data sets.

Alboran Sea (Copin-Montégut, 1993), the Strait of Gibraltar (Santana-Casiano et al., 2002), and the DYFAMED Site (Copin-Montégut and Bégovic, 2002; Touratier and Goyet, 2009). On a large scale, equations were applied using limited data sets such as the Meteor 51/2 cruise in OctoberNovember 2001 (Schneider et al., 2007), the Transmed cruise in May-June 2007 (Rivaro et al., 2010), and the Meteor 51/2 and DYFAMED time-series stations (Touratier and Goyet, 2011).

The proposed algorithm including surface data from multiple cruises, and on a large time span, presents a more representative relationship to estimate $\mathrm{A}_{\mathrm{T}}$ from $\mathrm{S}$ and $T$ than the previously presented equations (Table 3 ). In Eq. (1), $T$ and $\mathrm{S}$ contribute to $96 \%$ of the $\mathrm{A}_{\mathrm{T}}$ variability and the RMSE of $\pm 10.6 \mu \mathrm{mol} \mathrm{kg}^{-1}$ presents a significant improvement of the spatial and temporal estimations of $\mathrm{A}_{\mathrm{T}}$ in the Mediterranean Sea surface waters (mean difference $t$ test, $H=1 ; p=0.04$ ).

\subsection{Fitting $\mathrm{C}_{\mathrm{T}}$ in the Mediterranean Sea surface waters}

The surface $\mathrm{C}_{\mathrm{T}}$ concentrations are influenced by lateral and vertical mixing, photosynthesis, oxidation of organic matter and changes in temperature and salinity (Poisson et al., 1993; Takahashi et al., 1993). All these processes are directly or indirectly correlated with sea surface temperature (Lee et al., 2000). Hence, the parameterization of $\mathrm{C}_{\mathrm{T}}$ includes both physical (S and $T$ ) and/or biological parameters (Bakker et 
Table 2. Mean difference $t$ test for the $\mathrm{A}_{\mathrm{T}}$ algorithm between the training and validation data sets

\begin{tabular}{llll}
\hline & Training data set & Validation data set & \\
\hline RMSE $\left(\mu \mathrm{mol} \mathrm{kg} \mathrm{kg}^{-1}\right)$ & 10.60 & 10.34 & $\begin{array}{l}\text { Mean difference } t \text { test: } \\
H=0 ; p=0.83\end{array}$ \\
Mean residual $\left(\mu \mathrm{mol} \mathrm{kg}{ }^{-1}\right)$ & $2.64 \times 10^{-13} \pm 10.57$ & $0.91 \pm 10.30$ & $\begin{array}{l}\text { Mean difference } t \text { test: } \\
H=0 ; p=0.42\end{array}$ \\
\hline
\end{tabular}

Table 3. Performance of the different parameterizations for the estimation of $\mathrm{A}_{\mathrm{T}}$ applied independently to the training data set of this study.

\begin{tabular}{lllll}
\hline Region & Parameterization & RMSE $\left(\mu \mathrm{mol} \mathrm{kg}^{-1}\right)$ & $r^{2}$ & Reference \\
\hline Alboran Sea & $\mathrm{A}_{\mathrm{T}}=94.85(\mathrm{~S})-1072.6$ & \pm 16.61 & 0.92 & Copin-Montégut (1993) \\
DYFAMED site & $\mathrm{A}_{\mathrm{T}}=93.99(\mathrm{~S})-1038.1$ & \pm 16.31 & 0.92 & Copin-Montégut and Bégovic (2002) \\
Strait of Gibraltar & $\mathrm{A}_{\mathrm{T}}=92.28(\mathrm{~S})-968.7$ & \pm 16.48 & 0.92 & Santana-Casiano et al. (2002) \\
Mediterranean Sea & $\mathrm{A}_{\mathrm{T}}=73.7(\mathrm{~S})-285.7$ & \pm 26.11 & 0.68 & Schneider et al. (2007) \\
DYFAMED site & $\mathrm{A}_{\mathrm{T}}=99.26(\mathrm{~S})-1238.4$ & \pm 18.53 & 0.91 & Touratier and Goyet (2009) \\
Western Mediterranean & $\mathrm{A}_{\mathrm{T}}=95.25(\mathrm{~S})-1089.3$ & \pm 16.97 & 0.92 & Rivaro et al. (2010) \\
Eastern Mediterranean & $\mathrm{A}_{\mathrm{T}}=80.04(\mathrm{~S})-499.8$ & \pm 14.58 & 0.91 & Touratier and Goyet (2011) \\
Mediterranean Sea & $\mathrm{A}_{\mathrm{T}}=1 /\left(6.57 \times 10^{-5}+1.77-10^{-2}\right) /$ & \pm 13.81 & 0.92 & \\
Global relationship & $\mathrm{S}-\left(5.93-10^{-4}(\ln (\theta)) / \theta^{2}\right)$ & & 0.26 & Lee et al. (2006) \\
(subtropics) & $\mathrm{A}_{\mathrm{T}}=2305+58.66(\mathrm{~S}-35)+2.32(\mathrm{~S}-$ & \pm 40.50 & & \\
& $35)^{2}$ & & &
\end{tabular}

al., 1999; Bates et al., 2006; Koffi et al., 2010; Lee et al., 2000; Sasse et al., 2013).

The results of the 10-fold cross-validation analysis showed that a first-order polynome fits $\mathrm{C}_{\mathrm{T}}$ to $\mathrm{S}$ and $T$ with an RMSE of $16.25 \mu \mathrm{mol} \mathrm{kg}^{-1}$ and $r^{2}=0.87$. These values are comparable to the RMSE and $r^{2}$ found by previous empirical approaches applied in the eastern Atlantic (Bakker et al., 1999; Koffi et al., 2010). However, we found that a third-order polynome improved the RMSE and $r^{2}$ of the equation compared to the first-order fit (Eq. 2). Hence we will retain the large data set used to develop Eq. (2), where temperature and salinity explain $90 \%$ of the $\mathrm{C}_{\mathrm{T}}$ variability encountered in the Mediterranean Sea surface waters. The remaining $10 \%$ could be attributed to the biological and air-sea exchange contributions to the $\mathrm{C}_{\mathrm{T}}$ variability.

$$
\begin{aligned}
& C_{\mathrm{T}}=2234+38.15(S-38.2)-14.38(T-17.7)-4.48 \\
& (S-38.2)^{2}-1.43(S-38.2)(T-17.7)+9.62 \\
& (T-17.7)^{2}-1.10(S-38.2)^{3}+3.53(T-17.7)(S-38.2)^{2} \\
& +1.47(S-38.2)(T-17.7)^{2}-4.61(T-17.7)^{3},
\end{aligned}
$$

valid for $T>13^{\circ} \mathrm{C}$ and $36.30<\mathrm{S}<39.65 ; n=375, r^{2}=0.90$;

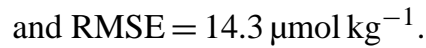

The $\mathrm{C}_{\mathrm{T}}$ parameterization developed in this study (Eq. 2) showed a higher uncertainty than that of $\mathrm{A}_{\mathrm{T}}$ regarding both RMSE and $r^{2}$. The estimation of $\mathrm{C}_{\mathrm{T}}$ in the mixed layer adds a high uncertainty due to the seasonal variability (Sabine et al., 2004). Also in surface waters, the $C_{T}$ are directly affected by air-sea exchange, and their concentrations will increase in response to the oceanic uptake of anthropogenic $\mathrm{CO}_{2}$.
Previous models accounted for the anthropogenic biases in the $\mathrm{C}_{\mathrm{T}}$ measurements by calculating the $\mathrm{C}_{\mathrm{T}}$ rate of increase (Bates, 2007; Lee et al., 2000; Sasse et al., 2013; Takahashi et al., 2014). However, in a study, Lee et al. (2000) also did not correct the $\mathrm{C}_{\mathrm{T}}$ concentrations for regions above $30^{\circ}$ latitude such as the Mediterranean Sea. In the following we will assess the importance of accounting or not for anthropogenic biases in the $\mathrm{C}_{\mathrm{T}}$ measurements. In that order we downloaded the monthly atmospheric $\mathrm{pCO}_{2}$ concentrations measured from 1999 to 2013 at the Lampedusa Island station (Italy) from the World Data Centre for Greenhouse Gases (http://ds.data.jma.go.jp/gmd/wdcgg/). Following the method described by Sasse et al. (2013), we corrected the $C_{T}$ measurements to the nominal year of 2005 and applied the same 10-fold cross-validation analysis using data with and without anthropogenic $C_{\mathrm{T}}$ corrections. We found that the RMSE of the $\mathrm{C}_{\mathrm{T}}$ model trained using measurements with anthropogenic corrections is $13.9 \mu \mathrm{mol} \mathrm{kg}{ }^{-1}$, which is not significantly different from the model trained using measurements without anthropogenic corrections (Eq. 2; $\mathrm{RMSE}=14.3 \mu \mathrm{mol} \mathrm{kg}{ }^{-1}$ ).

The yearly increase of $\mathrm{C}_{\mathrm{T}}$ concentrations is difficult to assess due to the wide spatial distribution of the training data set used to generate Eq. (2). Hence, we will refer to the monthly $\mathrm{C}_{\mathrm{T}}$ concentrations measured between 1998 and 2013 at the DYFAMED time-series station. We found that the rate of increase in $C_{\mathrm{T}}$ concentrations at the DYFAMED site was $0.99 \mu \mathrm{mol} \mathrm{kg}{ }^{-1} \mathrm{yr}^{-1}$ (Fig. 3), which is consistent with the anthropogenic $C_{\mathrm{T}}$ correction rate used in the previous studies of Lee et al. (2000), Bates (2007), and Sasse et al. (2013). 


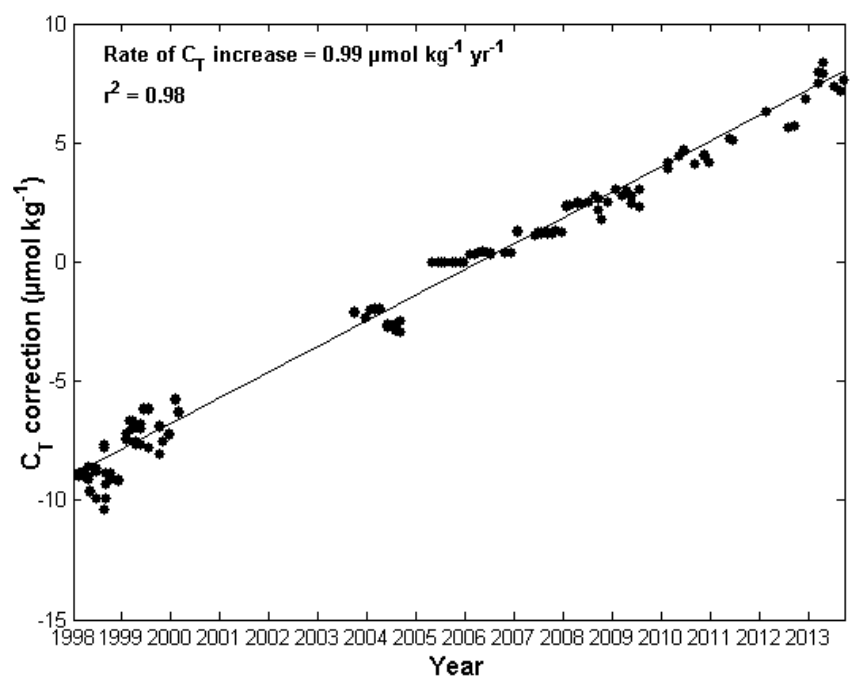

Figure 3. Rate of increase applied to correct the $\mathrm{C}_{\mathrm{T}}$ measurements in reference to the year 2005 .

The rate of increase in $\mathrm{C}_{\mathrm{T}}$ concentrations of $0.99 \mu \mathrm{mol} \mathrm{kg}^{-1} \mathrm{yr}^{-1}$ as well as the RMSE difference of $\pm 0.4 \mu \mathrm{mol} \mathrm{kg}{ }^{-1}$ between the two models (with or without anthropogenic corrections) are both smaller than the uncertainty of the $C_{T}$ measurements of at least $\pm 2 \mu \mathrm{mol} \mathrm{kg}-1$ (Millero, 2007). A recent study also showed that the uncertainty of the $\mathrm{C}_{\mathrm{T}}$ measurements can be significantly higher than $\pm 2 \mu \mathrm{mol} \mathrm{kg}{ }^{-1}$, as most laboratories reported values of $\mathrm{C}_{\mathrm{T}}$ for the measures that were within a range of $\pm 10 \mu \mathrm{mol} \mathrm{kg}{ }^{-1}$ of the stated value (Bockmon and Dickson, 2015).

Between 1998 and 2013, the $\mathrm{C}_{\mathrm{T}}$ concentrations measured at the DYFAMED time-series station showed a slightly increasing trend $\left(r^{2}=0.05\right)$. The increase in $\mathrm{C}_{\mathrm{T}}$ concentrations in response to elevated atmospheric $\mathrm{CO}_{2}$ was masked by the high seasonal variations. For example, during the year 1999 the variation in $\mathrm{C}_{\mathrm{T}}$ concentrations reached as high as $100 \mu \mathrm{mol} \mathrm{kg}^{-1}$ (Fig. 4a). Also, there is a clear seasonal cycle of $\mathrm{C}_{\mathrm{T}}$ in the DYFAMED station (Fig. 4b). In the summer, the $\mathrm{C}_{\mathrm{T}}$ starts to increase gradually, reaching a maximum of $2320 \mu \mathrm{mol} \mathrm{kg}^{-1}$ during the winter season, after which a gradual decrease is observed to reach a minimum of $2200 \mu \mathrm{mol} \mathrm{kg}{ }^{-1}$ by the end of spring. The seasonal cycle can be explained by the counter effect of temperature and biology on the $\mathrm{C}_{\mathrm{T}}$ variations. During the spring, the increasing effect of warming of $\mathrm{pCO}_{2}$ is counteracted by the photosynthetic activity that lowers the $\mathrm{C}_{\mathrm{T}}$. During the winter, the decreasing effect of cooling on $\mathrm{pCO}_{2}$ is counteracted by the upwelling of deep waters rich in $\mathrm{C}_{\mathrm{T}}$ (Hood and Merlivat, 2001; Takahashi et al., 1993). This shows that the $\mathrm{C}_{\mathrm{T}}$ concentrations were more affected by the seasonal variations than by anthropogenic forcing.

Considering the small differences in the RMSE obtained by the two models, the uncertainties in the $\mathrm{C}_{\mathrm{T}}$ measurements,
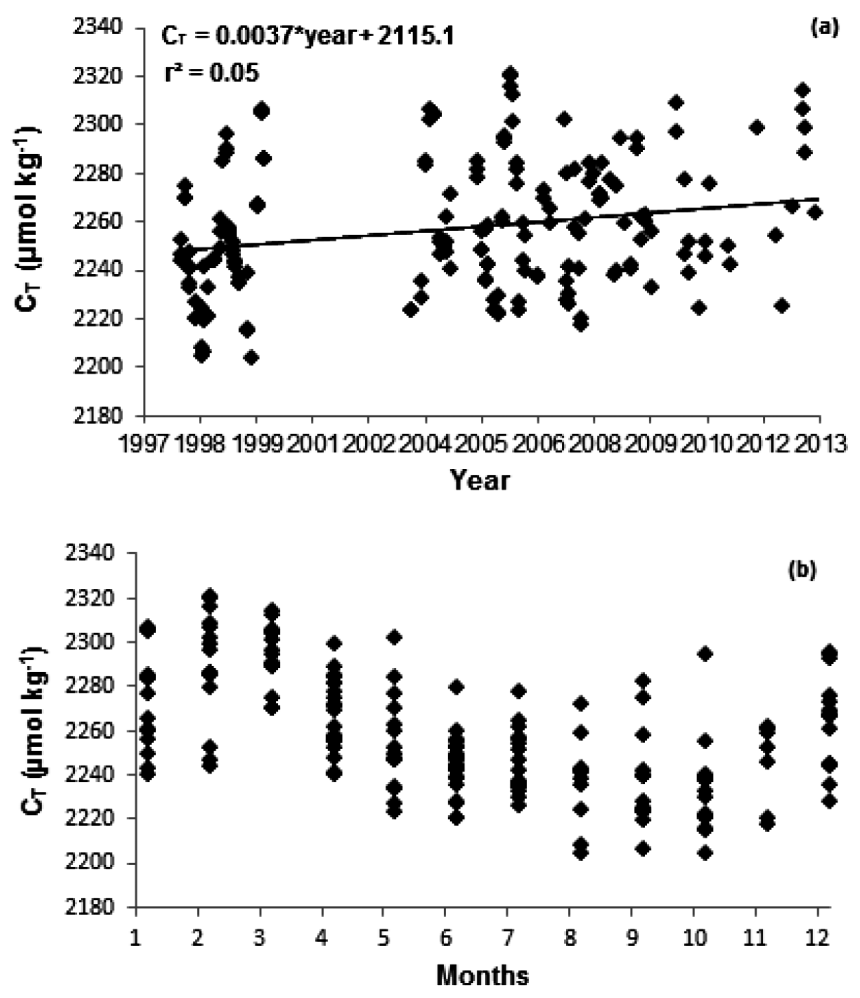

Figure 4. (a) Temporal and (b) seasonal variations of $\mathrm{C}_{\mathrm{T}}$ measured at the DYFAMED time-series station between 1998 and 2013.

and the clear signal of the seasonal variations, no corrections were made to account for the rising atmospheric $\mathrm{CO}_{2}$ concentrations. Also, the dynamic overturning circulation in the Mediterranean Sea plays an effective role in absorbing the anthropogenic $\mathrm{CO}_{2}$ and transports it from the surface to the interior of the basins (Hassoun et al., 2015a; Lee et al., 2011).

The residuals of the data set used to generate the thirdorder polynomial fit for $\mathrm{C}_{\mathrm{T}}$ are presented in Fig. 5a. Most of the $\mathrm{C}_{\mathrm{T}}$ residuals (330 out of 360 ) were within a range of $\pm 18 \mu \mathrm{mol} \mathrm{kg}{ }^{-1}(1 \sigma)$. In contrast, only few residuals (12 out of 360) reached up to $\pm 50 \mu \mathrm{mol} \mathrm{kg}-1(1 \sigma)$. Applying the $\mathrm{C}_{\mathrm{T}}$ algorithm to the testing data set (Fig. 5b) yields a mean residual of $4.5 \pm 17 \mu \mathrm{mol} \mathrm{kg}{ }^{-1}(1 \sigma)$, which is close to the uncertainties of our $\mathrm{C}_{\mathrm{T}}$ relationship. The high residuals observed in this study are consistent with the results of the optimal multiple linear regression performed by Lovato and Vichi (2015), where the largest discrepancies between observations and reconstructed data were detected at the surface layer with RMSE higher than $\pm 20 \mu \mathrm{mol} \mathrm{kg}{ }^{-1}$. To make sure that the $\mathrm{C}_{\mathrm{T}}$ algorithm does not overfit the data, we conducted the same analysis performed on the $\mathrm{A}_{\mathrm{T}}$ data sets. The results show that for both the RMSE and mean residual we cannot reject the null hypothesis (that assumes equals means) between the training and validation data sets (Table 4).

Considering the high uncertainties of the $\mathrm{C}_{\mathrm{T}}$ measurements, the seasonal variations, and the anthropogenic forcing, Eq. (2) presents the first parameterization for $C_{T}$ in 
Table 4. Mean difference $t$ test for the $\mathrm{C}_{\mathrm{T}}$ algorithm between the training and validation data sets

\begin{tabular}{llll}
\hline & Training data set & Validation data set & \\
\hline $\operatorname{RMSE}\left(\mu \mathrm{mol} \mathrm{kg} \mathrm{kg}^{-1}\right)$ & 14.3 & 16.2 & $\begin{array}{l}\text { Mean difference } t \text { test: } \\
\mathrm{H}=0 ; p=0.04 \\
\text { Mean residual }\left(\mu \mathrm{mol} \mathrm{kg}{ }^{-1}\right)\end{array}$ \\
& $-1.5 \times 10^{-12} \pm 14.2$ & $4.5 \pm 17$ & $\begin{array}{l}\text { Mean difference } t \text { test: } \\
\mathrm{H}=0 ; p=0.06\end{array}$ \\
\hline
\end{tabular}

the Mediterranean Sea surface waters, with an RMSE of $\pm 14.3 \mu \mathrm{mol} \mathrm{kg} \mathrm{kg}^{-1}(1 \sigma)$ and a $r^{2}=0.90$ (Eq. 2).

\subsection{Spatial and seasonal variability of $A_{T}$ and $C_{T}$ in surface waters}

The ranges of the 2005-2012 average annual climatologies of WOA13 are from 35.91 to 39.50 for $\mathrm{S}$ and from 16.50 to $23.57^{\circ} \mathrm{C}$ for $T$ (Locarnini et al., 2013; Zweng et al., 2013). However, a wider range is observed for the seasonal climatologies, especially during the winter season where $T$ ranges from 9.05 to $18.43^{\circ} \mathrm{C}$. The estimations of $\mathrm{A}_{\mathrm{T}}$ and $\mathrm{C}_{\mathrm{T}}$ in surface waters from Eq. (1) and (2) respectively are only applicable in the appropriate ranges of $T>13^{\circ} \mathrm{C}$ and $36.3<\mathrm{S}<39.65$. Hence, the surface water's $\mathrm{A}_{\mathrm{T}}$ and $\mathrm{C}_{\mathrm{T}}$ concentrations were mapped only where $T$ and $S$ were within the validity range of Eq. (1) and (2) respectively. Excluding few near-shore areas and the influence of cold Atlantic waters in winter, the ranges in which Eq. (1) and Eq. (2) can be applied are within those of the climatological products of $T$ and $\mathrm{S}$ of the WOA13 (Fig. 6).

The mapped climatologies for 2005-2012 at 5m depth show a strong increase in the eastward gradient for both $\mathrm{A}_{\mathrm{T}}$ and $\mathrm{C}_{\mathrm{T}}$ with the highest concentrations always found in the eastern Mediterranean (Fig. 7). The minimum values of $2400 \mu \mathrm{mol} \mathrm{kg}^{-1}$ for $\mathrm{A}_{\mathrm{T}}$ and $2100 \mu \mathrm{mol} \mathrm{kg}-1$ for $\mathrm{C}_{\mathrm{T}}$ are found near the Strait of Gibraltar and the maximum values of $2650 \mu \mathrm{mol} \mathrm{kg} \mathrm{kg}^{-1}$ and $2300 \mu \mathrm{mol} \mathrm{kg}{ }^{-1}$ are found in the Levantine and Aegean sub-basins for $\mathrm{A}_{\mathrm{T}}$ and $\mathrm{C}_{\mathrm{T}}$ respectively.

The $A_{T}$ parameterization of this study detects a clear signature of the alkaline waters entering through the Strait of Gibraltar that remains traceable to the Strait of Sicily as also shown by Cossarini et al. (2015). In the eastern basin the positive balance between evaporation and precipitation contributes to the increasing surface $\mathrm{A}_{\mathrm{T}}$. Local effects from some coastal areas such as the Gulf of Gabes and riverine inputs from the Rhone and Po rivers are also detected.

Our results for surface $A_{T}$ have a similar spatial pattern and range as the annual climatology of Cossarini et al. (2015) which simulates surface $A_{T}$ values from 2400 to $2700 \mu \mathrm{mol} \mathrm{kg} \mathrm{kg}^{-1}$. The main difference is marked in the upper ends of the Adriatic and Aegean sub-basins where our algorithm predicts $A_{\mathrm{T}}$ values around $2400-2500 \mu \mathrm{mol} \mathrm{kg} \mathrm{kg}^{-1}$, whereas the analysis of Cossarini et al. (2015) yields a maximum of $2700 \mu \mathrm{mol} \mathrm{kg}-1$ in these regions. Regressions in
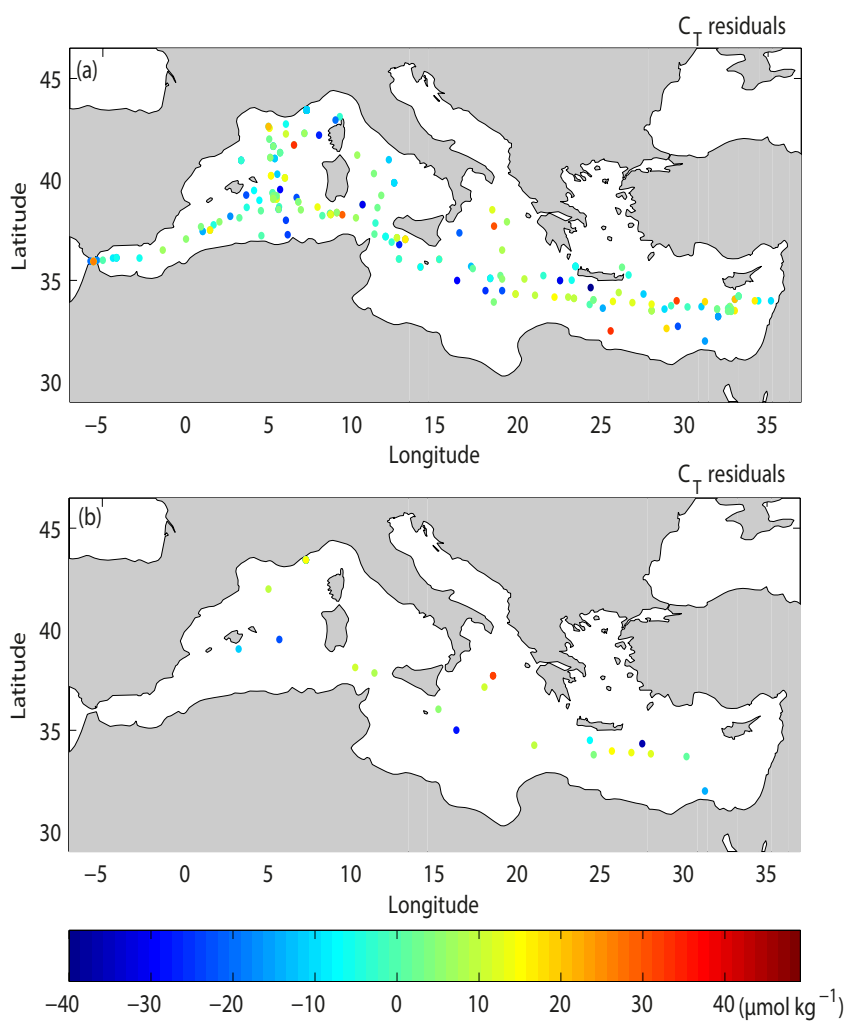

Figure 5. Comparison of the predicted $\mathrm{C}_{\mathrm{T}}$ values from the $\mathrm{C}_{\mathrm{T}}$ algorithm given in Eq. (2) with measurements which are (a) included or (b) excluded when deriving the fit.

regions of high alkaline riverine inputs indicate a negative correlation between alkalinity and salinity (Luchetta et al., 2010). Hence, eastern marginal seas such as the Adriatic and Aegean sub-basins have high $\mathrm{A}_{\mathrm{T}}$ concentrations due to the freshwater inputs having enhanced alkalinity loads (Cantoni et al., 2012; Souvermezoglou et al., 2010). This shows the sensitivity of our algorithms to temperature and salinity especially in areas that are more influenced by continental inputs such as the Po and other local rivers in the northern Adriatic and inputs of the brackish Black Sea water through the Dardanelles Strait as well as by the river runoff from the Greek and Turkish mainland in the northern Aegean (Fig. 7a).

At the surface, the basin-wide distributions of $\mathrm{C}_{\mathrm{T}}$ are affected by physical processes and their gradient is similar to that of $\mathrm{A}_{\mathrm{T}}$ (Fig. 7b). The lowest $\mathrm{C}_{\mathrm{T}}$ concentrations are found 

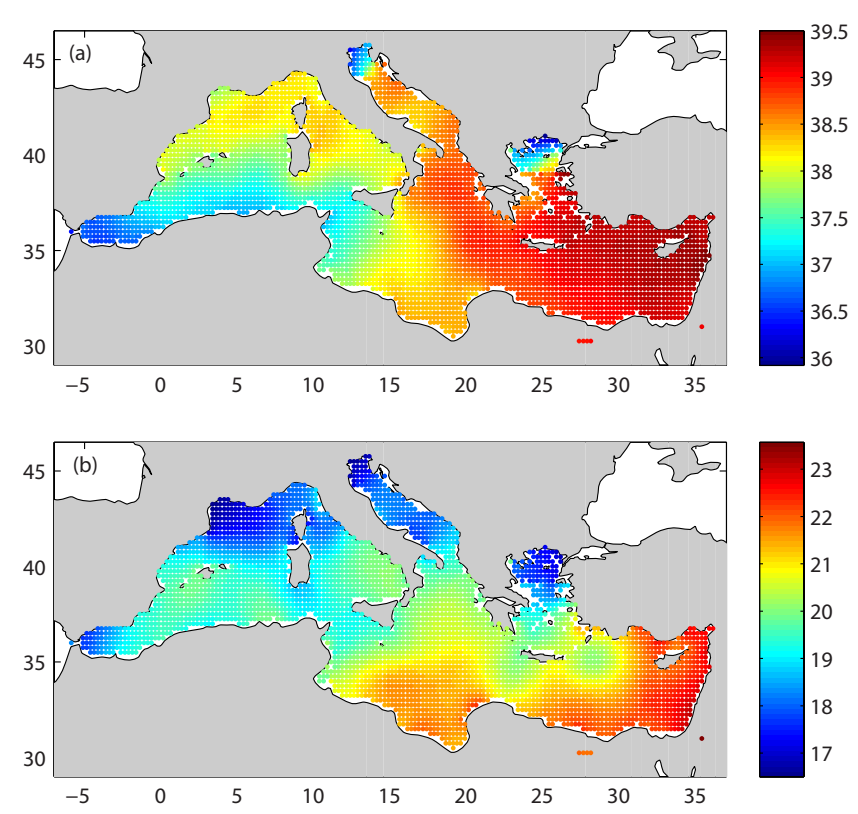

Figure 6. The 7-year averages (2005-2012) of (a) sea surface salinity and (b) sea surface temperature climatological fields of the WOA13 (Locarnini et al., 2013; Zweng et al., 2013).
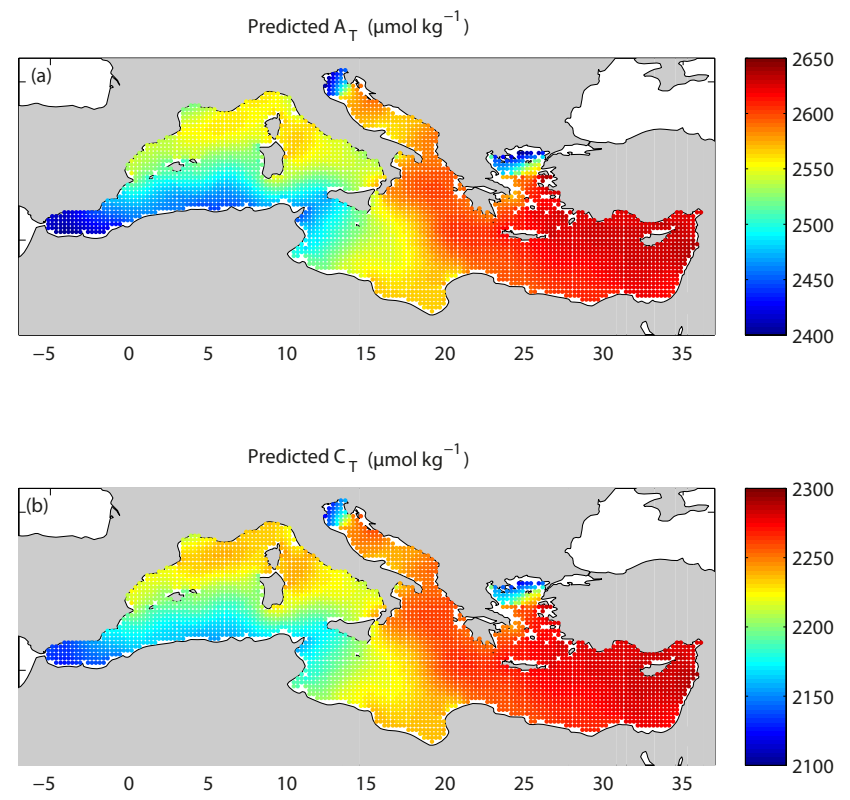

Figure 7. The 7-year averages of spatial variability for (a) surface $\mathrm{A}_{\mathrm{T}}$ predicted from Eq. (1) and (b) surface $\mathrm{C}_{\mathrm{T}}$ predicted from Eq. (2), applied to the 2005-2012 climatological fields of $\mathrm{S}$ and $T$ from the WOA13.

in the zone of the inflowing Atlantic water and increases toward the east in part due to evaporation as also shown by Schneider et al. (2010). Our results for surface $C_{T}$ have a similar range as the optimal linear regression performed by Lovato and Vichi (2015) which estimates surface $C_{T}$ values
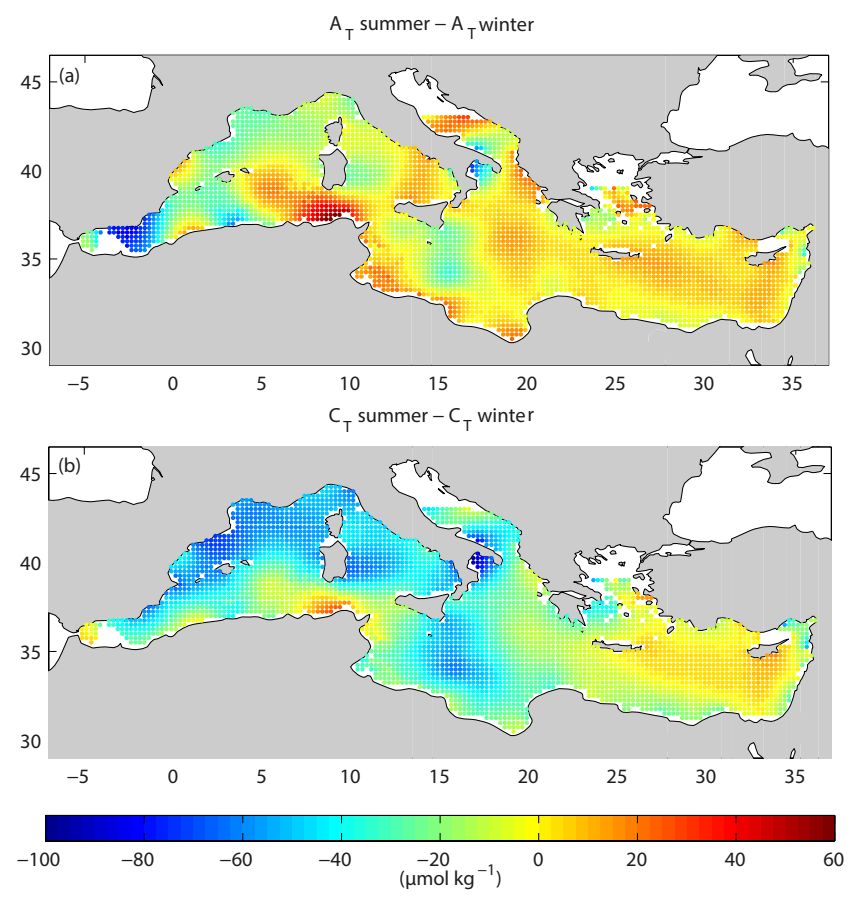

Figure 8. Distribution of the summer-winter differences of (a) surface $A_{T}$ predicted from Eq. (1) and (b) surface $C_{T}$ predicted from Eq. (2), applied to the 2005-2012 climatological fields of S and $T$ from the WOA13.

from 2180 to $2260 \mu \mathrm{mol} \mathrm{kg}^{-1}$. Moreover, the results show that the Mediterranean Sea is characterized by $\mathrm{C}_{\mathrm{T}}$ values that are much higher (100-200 $\mu$ mol kg ${ }^{-1}$ higher) than those observed in the Atlantic Ocean at the same latitude (Key et al., 2004).

Overall, the western basin has a lower surface $C_{T}$ content than the eastern basin, which could be explained by the eastward decrease of the Mediterranean Sea trophic gradient (Lazzari et al., 2012). The higher rate of inorganic carbon consumption by photosynthesis in the western basin can lead to the depletion of $\mathrm{C}_{\mathrm{T}}$ in the surface waters, whereas the ultra-oligotrophic state in the eastern basin can lead to a high remineralization rate that consumes oxygen and enriches surface waters with $\mathrm{C}_{\mathrm{T}}$ (Moutin and Raimbault, 2002).

The magnitude of the seasonal variability between summer and winter for $\mathrm{A}_{\mathrm{T}}$ and $\mathrm{C}_{\mathrm{T}}$ is shown in Fig. 8. Unlike the 7-year averages, the seasonal climatological variations (2005-2012) of $\mathrm{A}_{\mathrm{T}}$ have different spatial patterns than those of $\mathrm{C}_{\mathrm{T}}$. Overall the summer-wintertime differences for $\mathrm{A}_{T}$ have an increasing eastward gradient (Fig. 8a). The largest magnitudes are marked in the Alboran Sea with differences reaching up to $-80 \mu \mathrm{mol} \mathrm{kg}^{-1}$; the negative difference implies that during the winter inflowing surface Atlantic water has higher $\mathrm{A}_{T}$ concentrations than in summer. Higher wintertime than summertime $A_{T}$ concentrations are also observed in the Balearic, Ligurian and the south-western Ionian sub-basins but with a less-pronounced 
seasonality $\left(\sim-30 \mu \mathrm{mol} \mathrm{kg}{ }^{-1}\right)$. For these three sub-basins, the $\mathrm{C}_{\mathrm{T}}$ has a higher summer-winter magnitude than $\mathrm{A}_{\mathrm{T}}$ $\left(\sim-70 \mu \mathrm{mol} \mathrm{kg}^{-1}\right)$. The winter cooling of surface waters increases their density and promotes a mixing with deeper water. Thus, the enrichment in wintertime likely reflects the upwelling of deep waters that have accumulated $\mathrm{A}_{\mathrm{T}}$ and $\mathrm{C}_{\mathrm{T}}$ from the remineralization of organic matter, respiration, and the dissolution of $\mathrm{CaCO}_{3}$. The seasonality is more pronounced for $\mathrm{C}_{\mathrm{T}}$, which likely reflects the stronger response of $\mathrm{C}_{\mathrm{T}}$ to biological processes than $\mathrm{A}_{\mathrm{T}}$ (Takahashi et al., 1993).

In the Algerian sub-basin and along the coasts of Tunisia and Libya, the seasonality is inverted with higher $\mathrm{A}_{T}$ and $\mathrm{C}_{\mathrm{T}}$ concentrations prevailing in the summer. The African coast is an area of coastal downwelling during the winter season. However, during summer the coastal upwelling appears in response to turning of the wind near the coast toward the west (Bakun and Agostini, 2001). In general, the magnitude of the $\mathrm{A}_{\mathrm{T}}$ seasonal variability is higher in summer than in winter for the eastern basin and more particularly in the Ionian and Levantine sub-basins. During this season, strong evaporation takes place, which induces an increase of $\mathrm{A}_{\mathrm{T}}$ concentrations (Schneider et al., 2007). In the eastern basin, the high evaporation during the summer has a smaller effect on the $\mathrm{C}_{\mathrm{T}}$, and magnitudes reach their maxima in the Levantine sub-basin $\left(\sim+20 \mu \mathrm{mol} \mathrm{kg}^{-1}\right)$. During wintertime the western basin and the south-east of Sicily appear to be dominated by higher $\mathrm{C}_{\mathrm{T}}$ concentrations than the rest of the eastern basin, where the summer $\mathrm{C}_{\mathrm{T}}$ concentrations prevail (Fig. 8b). During winter the high $\mathrm{C}_{\mathrm{T}}$ concentrations that coincide with low sea surface temperature in the western basin could result from the deepening of the mixed layer and could be enhanced by the upwelling associated with the Tramontane-Mistral winds that blow from the south of France and reach the Balearic Islands and the Spanish coast.

\section{Summary}

The $\mathrm{A}_{\mathrm{T}}$ and $\mathrm{C}_{\mathrm{T}}$ algorithms are derived from a compilation of 490 and 426 quality controlled surface measurements respectively, collected between 1999 and 2013 in the Mediterranean Sea. A second-order polynomial relating $\mathrm{A}_{\mathrm{T}}$ to both $\mathrm{S}$ and $\mathrm{T}$ yielded a lower RMSE $\left( \pm 10.4 \mu \mathrm{mol} \mathrm{kg}^{-1}\right)$ and a higher $r^{2}(0.96)$ than a linear fit deriving $\mathrm{A}_{\mathrm{T}}$ from $\mathrm{S}$ alone. This confirmed the important contribution of temperature to the $A_{T}$ variability. Hence, temperature should be included in future algorithms to help better constrain the surface $A_{T}$ variations. The proposed second-order polynomial had a lower RMSE than other studies when we applied their respective algorithms to the same training data set. In this study we propose an improved and more global relationship to estimate the $\mathrm{A}_{\mathrm{T}}$ spatial and temporal variations in the Mediterranean Sea surface waters.

The $\mathrm{C}_{\mathrm{T}}$ parameterization is a first attempt to estimate the surface variations in the Mediterranean Sea. A third-order polynomial is suggested to fit the $\mathrm{C}_{\mathrm{T}}$ to $T$ and $\mathrm{S}$ with a RMSE of $\pm 14.3 \mu \mathrm{mol} \mathrm{kg}{ }^{-1}$. The biological contributions to the $\mathrm{C}_{\mathrm{T}}$ variations were less pronounced than the physical processes. The contributions of to the physical processes and biology to the $C_{T}$ variability were 90 and $10 \%$ respectively. In terms of anthropogenic forcing, the $\mathrm{C}_{\mathrm{T}}$ rate of increase of $0.99 \mu \mathrm{mol} \mathrm{kg}{ }^{-1} \mathrm{yr}^{-1}$ was significantly lower than the uncertainty of the measurements than can reach $\pm 10 \mu \mathrm{mol} \mathrm{kg}^{-1}$ between different laboratories. Moreover, the $\mathrm{C}_{\mathrm{T}}$ concentrations were more affected by the seasonal variations than the increase of atmospheric $\mathrm{CO}_{2}$.

We propose to use Eqs. (1) and (2) for the estimation of surface $A_{T}$ and $C_{T}$ in the Mediterranean Sea when salinity and temperature of the area are available and are in the appropriate ranges of the equations. However, in the eastern marginal seas, especially the northern Adriatic and northern Aegean, there is a need to develop a more specific equation that minimizes the errors in these areas. Hence, it is important to enrich the existing data set by an extensive sampling program such as the Med-SHIP initiative (CIESM, 2012) in order to improve the modelling of the carbonate system over the whole Mediterranean Sea.

Acknowledgements. The authors would like to thank all parties that have contributed to the data provision.

- The Sesame IT4 and Moose-GE cruise data were provided through SeaDataNet - Pan-European infrastructure for ocean and marine data management (http://www.seadatanet.org).

- The DYFAMED time series have been provided by the Oceanological Observatory of Villefranche-sur-Mer (L. Coppola). This project is funded by CNRS-INSU and ALLENVI through the MOOSE observing network.

- The Transmed cruise data were provided by P. Rivaro, A. Russo, and V. Kovacevic. The Transmed cruise is part of the VECTOR project, funded by the Ministry of Education, University and Research, the Ministry of Economy and Finance, the Ministry of the Environment and Protection of Natural Resources, and the Ministry of Agriculture and Forestry with an Integrated Special Fund for Research (FISR).

- The MedSEA 2013 cruise data were provided by the University of Perpignan Via Domitia, Institut de Modélisation et d'Analyse en Géo-Environnements et Santé, ESPACE-DEV (C. Goyet and A. E. R. Hassoun). This project was funded by the EC Mediterranean Sea Acidification in a changing climate project (MedSeA; grant agreement 265103).

- We would also like to thank the SNAPO-CO 2 (Service National d'Analyse des paramètres Océaniques du $\mathrm{CO}_{2}$ ) for their contribution in measuring some of the $\mathrm{A}_{\mathrm{T}}$ and $\mathrm{C}_{\mathrm{T}}$ samples.

The authors are also grateful to the National Council for Scientific Research (CNRS) in Lebanon for the PhD thesis scholarship granted to Gemayel Elissar.

Edited by: C. Heinze 


\section{References}

Álvarez, M., Sanleón-Bartolomé, H., Tanhua, T., Mintrop, L., Luchetta, A., Cantoni, C., Schroeder, K., and Civitarese, G.: The $\mathrm{CO}_{2}$ system in the Mediterranean Sea: a basin wide perspective, Ocean Sci., 10, 69-92, 2014,

http://www.ocean-sci.net/10/69/2014/.

Bakker, D. C. E., de Baar, H. J. W., and de Jong, E.: The dependence on temperature and salinity of dissolved inorganic carbon in East Atlantic surface waters, Mar. Chem., 65, 263-280, 1999.

Bakun, A. and Agostini, V. N.: Seasonal patterns of wind-induced upwelling/downwelling in the Mediterranean Sea, Sci. Mar., 65, 243-257, 2001.

Bates, N. R.: Interannual variability of the oceanic $\mathrm{CO}_{2}$ sink in the subtropical gyre of the North Atlantic Ocean over the last 2 decades, J. Geophys. Res., 112, C09013, doi:10.1029/2006jc003759, 2007.

Bates, N. R., Pequignet, A. C., and Sabine, C. L.: Ocean carbon cycling in the Indian Ocean: 1 . Spatiotemporal variability of inorganic carbon and air-sea $\mathrm{CO}_{2}$ gas exchange, Global Biogeochem. Cy., 20, GB3020, doi:10.1029/2005GB002491, 2006.

Bégovic, M. and Copin-Montégut, C.: Processes controlling annual variations in the partial pressure of $\mathrm{CO}_{2}$ in surface waters of the central northwestern Mediterranean Sea (Dyfamed site), Deep Sea Res. Part II Top Stud. Oceanogr., 49, 2031-2047, 2002.

Bégovic, M. and Copin, C.: Alkalinity and $\mathrm{pH}$ measurements on water bottle samples during THALASSA cruise PROSOPE, available at: http://doi.pangaea.de/10.1594/PANGAEA.805265 (last access: 20 August 2015), 2013.

Bockmon, E. E. and Dickson, A. G.: An inter-laboratory comparison assessing the quality of seawater carbon dioxide measurements, Mar. Chem., 171, 36-43, 2015.

Breiman, L.: Stacked regressions, Mach. Learn, 24, 49-64, 1996.

Cantoni, C., Luchetta, A., Celio, M., Cozzi, S., Raicich, F., and Catalano, G.: Carbonate system variability in the Gulf of Trieste (North Adriatic Sea), Estuar. Coast. Shelf Sci., 115, 51-62, 2012.

CIESM: Designing Med-SHIP: a Program for repeated oceanographic surveys, CIESM, Monaco, 164 pp., 2012.

Copin-Montégut, C.: Alkalinity and carbon budgets in the Mediterranean Sea, Global Biogeochem. Cy., 7, 915-925, 1993.

Copin-Montégut, C. and Bégovic, M.: Distributions of carbonate properties and oxygen along the water column $(0-2000 \mathrm{~m})$ in the central part of the NW Mediterranean Sea (Dyfamed site): influence of winter vertical mixing on air-sea $\mathrm{CO}_{2}$ and $\mathrm{O}_{2}$ exchanges, Deep Sea Res. Part II Top Stud. Oceanogr., 49, 2049-2066, 2002.

Cossarini, G., Lazzari, P., and Solidoro, C.: Spatiotemporal variability of alkalinity in the Mediterranean Sea, Biogeosciences, 12, 1647-1658, doi:10.5194/bg-12-1647-2015, 2015.

D’Ortenzio, F., Antoine, D., and Marullo, S.: Satellite-driven modeling of the upper ocean mixed layer and air-sea $\mathrm{CO}_{2}$ flux in the Mediterranean Sea, Deep Sea Res. Part I Oceanogr. Res. Pap., 55, 405-434, 2008.

Goyet, C. and Davis, D.: Estimation of total $\mathrm{CO}_{2}$ concentration throughout the water column, Deep Sea Res. Part I Oceanogr. Res. Pap., 44, 859-877, 1997.

Goyet, C., Hassoun, A. E. R., and Gemayel, E.: Carbonate system during the May 2013 MedSeA cruise, PANGAEA, available at: http://doi.pangaea.de/10.1594/PANGAEA.841933 (last access: 20 August 2015), 2015.
Hassoun, A. E. R., Gemayel, E., Krasakopoulou, E., Goyet, C., Abboud-Abi Saab, M., Guglielmi, V., Touratier, F., and Falco, C.: Acidification of the Mediterranean Sea from anthropogenic carbon penetration, Deep Sea Res. Part I Oceanogr. Res. Pap., 102, 1-15, 2015a.

Hassoun, A. E. R., Gemayel, E., Krasakopoulou, E., Goyet, C., Abboud-Abi Saab, M., Ziveri, P., Touratier, F., Guglielmi, V., and Falco, C.: Modeling of the total alkalinity and the total inorganic carbon in the Mediterranean Sea, J. Water Resour. Ocean. Sci., 4, 24-32, 2015b.

Hood, E. M. and Merlivat, L.: Annual to interannual variations of $\mathrm{fCO}_{2}$ in the northwestern Mediterranean Sea: Results from hourly measurements made by CARIOCA buoys, 1995-1997, J. Mar. Res., 59, 113-131, 2001.

Huertas, E.: Hydrochemistry measured on water bottle samples during Al Amir Moulay Abdallah cruise CARBOGIB-2, Unidad de Tecnología Marina - Consejo Superior de Investigaciones Científicas, doi:10.1594/PANGAEA.618899, 2007a.

Huertas, E.: Hydrochemistry measured on water bottle samples during Al Amir Moulay Abdallah cruise CARBOGIB-3, Unidad de Tecnología Marina - Consejo Superior de Investigaciones Científicas, doi:10.1594/PANGAEA.618898, 2007b.

Huertas, E.: Hydrochemistry measured on water bottle samples during Al Amir Moulay Abdallah cruise CARBOGIB-4, Unidad de Tecnología Marina - Consejo Superior de Investigaciones Científicas, doi:10.1594/PANGAEA.618897, 2007c.

Huertas, E.: Hydrochemistry measured on water bottle samples during Al Amir Moulay Abdallah cruise CARBOGIB-5, Unidad de Tecnología Marina - Consejo Superior de Investigaciones Científicas, doi:10.1594/PANGAEA.618896, 2007d.

Huertas, E.: Hydrochemistry measured on water bottle samples during Al Amir Moulay Abdallah cruise CARBOGIB-6, Unidad de Tecnología Marina - Consejo Superior de Investigaciones Científicas, doi:10.1594/PANGAEA.618895, 2007e.

Huertas, E.: Hydrochemistry measured on water bottle samples during Garcia del Cid cruise GIFT-1, Unidad de Tecnología Marina - Consejo Superior de Investigaciones Científicas, doi:10.1594/PANGAEA.618816, 2007f.

Huertas, E.: Hydrochemistry measured on water bottle samples during Garcia del Cid cruise GIFT-2, Unidad de Tecnología Marina - Consejo Superior de Investigaciones Científicas, doi:10.1594/PANGAEA.618815, 2007g.

Huertas, E.: Hydrochemistry measured on water bottle samples during Garcia del Cid cruise GIFT-3, Unidad de Tecnología Marina - Consejo Superior de Investigaciones Científicas, doi:10.1594/PANGAEA.618815, 2007h.

Hydes, D., Jiang, Z., Hartman, M. C., Campbell, J. M., Hartman, S. E., Pagnani, M. R., and Kelly-Gerreyn, B. A.: Surface DIC and TALK measurements along the M/V Pacific Celebes VOS Line during the 2007-2012 cruises. available at: http://cdiac.ornl.gov/ ftp/oceans/VOS_Pacific_Celebes_line/ (last access: 20 August 2015). Carbon Dioxide Information Analysis Center, Oak Ridge National Laboratory, US Department of Energy, Oak Ridge, Tennessee, doi:10.3334/CDIAC/OTG.VOS_PC_2007-2012, 2012.

Ishii, M., Saito, S., Tokieda, T., Kawano, T., Matsumoto, K., and Inoue, H. Y.: Variability of surface layer $\mathrm{CO}_{2}$ parameters in the Western and Central Equatorial Pacific. In: Global Environmental Change in the Ocean and on Land, edited by: Shiyomi M., 
Koizumi, K. H., Tsuda, A., Awaya, Y., TERRAPUB, Tokyo, 2004.

Jiang, Z.-P., Tyrrell, T., Hydes, D. J., Dai, M., and Hartman, S. E.: Variability of alkalinity and the alkalinity-salinity relationship in the tropical and subtropical surface ocean, Global Biogeochem. Cy., 28, 729-742, doi:10.1002/2013gb004678, 2014.

Keeling, R. F., Najjar, R. P., Bender, M. L., and Tans, P. P.: What atmospheric oxygen measurements can tell us about the global carbon cycle, Global Biogeochem. Cy., 7, 37-67, 1993.

Key, R. M., Kozyr, A., Sabine, C. L., Lee, K., Wanninkhof, R., Bullister, J. L., Feely, R. A., Millero, F. J., Mordy, C., and Peng, T. H.: A global ocean carbon climatology: Results from Global Data Analysis Project (GLODAP), Global Biogeochem. Cy., 18, GB4031, doi:10.1029/2004gb002247, 2004.

Koeve, W., Duteil, O., Oschlies, A., Kähler, P., and Segschneider, J.: Methods to evaluate $\mathrm{CaCO}_{3}$ cycle modules in coupled global biogeochemical ocean models, Geosci. Model Dev., 7, 23932408, doi:10.5194/gmd-7-2393-2014, 2014.

Koffi, U., Lefèvre, N., Kouadio, G., and Boutin, J.: Surface $\mathrm{CO}_{2}$ parameters and air-sea $\mathrm{CO}_{2}$ flux distribution in the Eastern Equatorial Atlantic Ocean, J. Mar. Syst., 82, 135-144, 2010.

Krasakopoulou, E., Souvermezoglou, E., and Goyet, C.: Anthropogenic $\mathrm{CO}_{2}$ fluxes in the Otranto Strait (E. Mediterranean) in February 1995, Deep Sea Res. Part I Oceanogr. Res. Pap., 58, 1103-1114, 2011.

Lazzari, P., Solidoro, C., Ibello, V., Salon, S., Teruzzi, A., Béranger, K., Colella, S., and Crise, A.: Seasonal and inter-annual variability of plankton chlorophyll and primary production in the Mediterranean Sea: a modelling approach, Biogeosciences, 9, 217-233, doi:10.5194/bg-9-217-2012, 2012.

Lee, K., Wanninkhof, R., Feely, R. A., Millero, F. J., and Peng, T.H.: Global relationships of total inorganic carbon with temperature and nitrate in surface seawater, Global Biogeochem. Cy., 14, 979-994, 2000.

Lee, K., Tong, L. T., Millero, F. J., Sabine, C. L., Dickson, A. G., Goyet, C., Park, G.-H., Wanninkhof, R., Feely, R. A., and Key, R. M.: Global relationships of total alkalinity with salinity and temperature in surface waters of the world's oceans, Geophys. Res. Lett., 33, L19605, doi:10.1029/2007g1027207, 2006.

Lee, K., Sabine, C. L., Tanhua, T., Kim, T.-W., Feely, R. A., and Kim, H.-C.: Roles of marginal seas in absorbing and storing fossil fuel $\mathrm{CO}_{2}$, Energ. Environ. Sci., 4, 1133-1146, 2011.

Locarnini, R. A., Mishonov, A. V., Antonov, J. I., Boyer, T. P., Garcia, H. E., Baranova, O. K., Zweng, M. M., Paver, C. R., Reagan, J. R., Johnson, D. R., Hamilton, M., and Seidov, D.: World Ocean Atlas 2013, Volume 1: Temperature, NOAA Atlas NESDIS 73, 40 pp., 2013.

Louanchi, F., Boudjakdji, M., and Nacef, L.: Decadal changes in surface carbon dioxide and related variables in the Mediterranean Sea as inferred from a coupled data-diagnostic model approach, ICES J Mar Sci, 66, 1538-1546, 2009.

Lovato, T. and Vichi, M.: An objective reconstruction of the Mediterranean sea carbonate system, Deep Sea Res. Part I Oceanogr. Res. Pap., 98, 21-30, 2015.

Luchetta, A., Cantoni, C., and Catalano, G.: New observations of $\mathrm{CO}_{2}$ induced acidification in the northern Adriatic Sea over the last quarter century, Chem Ecol, 26, 1-17, 2010.

McNeil, B. I., Metzl, N., Key, R. M., Matear, R. J., and Corbiere, A.: An empirical estimate of the Southern Ocean air-sea $\mathrm{CO}_{2}$ flux, Global Biogeochem. Cy., 21, GB3011, doi:10.1029/2007gb002991, 2007.

Millero, F. J.: The Marine inorganic carbon cycle, Chem. Rev., 107, 308-341, 2007.

Millero, F. J., Lee, K., and Roche, M.: Distribution of alkalinity in the surface waters of the major oceans, Mar. Chem., 60, 111-130, 1998.

Moutin, T. and Raimbault, P.: Primary production, carbon export and nutrients availability in Western and Eastern Mediterranean Sea in early summer 1996 (MINOS cruise), J. Mar. Syst., 33-34, 273-288, 2002.

Omta, A. W., Dutkiewicz, S., and Follows, M. J.: Dependence of the ocean-atmosphere partitioning of carbon on temperature and alkalinity, Global Biogeochem. Cy., 25, GB1003, doi:10.1029/2010gb003839, 2011.

Perez, F. F., Rios, A. F., Pelegri, J. L., de la Paz, M., Alonso, F., Royo, E., Velo, A., Garcia-Ibanez, M., and Padin, X. A.: Carbon Data Obtained During the R/V Hesperides Cruise in the Atlantic Ocean on CLIVAR Repeat Hydrography Section A17, FICARAM XV, (20 March-2 May 2013). http://cdiac. ornl.gov/ftp/oceans/CLIVAR/A17_FICARAM_XV_2013/. Carbon Dioxide Information Analysis Center, Oak Ridge National Laboratory, US Department of Energy, Oak Ridge, Tennessee, doi:10.3334/CDIAC/OTG.CLIVAR_FICARAM_XV, 2013.

Poisson, A., Metzl, N., Brunet, C., Schauer, B., Bres, B., Ruiz-Pino, D., and Louanchi, F.: Variability of sources and sinks of $\mathrm{CO}_{2}$ in the western Indian and southern oceans during the year 1991, J. Geophys. Res., 98, 22759-22778, 1993.

Rivaro, P., Messa, R., Massolo, S., and Frache, R.: Distributions of carbonate properties along the water column in the Mediterranean Sea: Spatial and temporal variations, Mar. Chem., 121, 236-245, 2010.

Rödenbeck, C., Keeling, R. F., Bakker, D. C. E., Metzl, N., Olsen, A., Sabine, C., and Heimann, M.: Global surface-ocean $\mathrm{pCO}_{2}$ and sea-air $\mathrm{CO}_{2}$ flux variability from an observation-driven ocean mixed-layer scheme, Ocean Sci., 9, 193-216, 2013, http://www.ocean-sci.net/9/193/2013/.

Rohling, E. J., Abu-Zied, R. H., Casford, J. S. L., Hayes, A., and Hoogakker, B. A. A.: The marine environment: Present and past, in: The physical geography of the Mediterranean, edited by: Woodward, J. C., Oxford University Press, 33-67, 2009.

Sabine, C. L., Feely, R. A., Gruber, N., Key, R. M., Lee, K., Bullister, J. L., Wanninkhof, R., Wong, C. S., Wallace, D. W. R., Tilbrook, B., Millero, F. J., Peng, T.-H., Kozyr, A., Ono, T., and Rios, A. F.: The oceanic sink for anthropogenic $\mathrm{CO}_{2}$, Science, 305, 367-371, 2004.

Santana-Casiano, J. M., Gonzalez-Davila, M., and Laglera, L. M.: The carbon dioxide system in the Strait of Gibraltar, Deep Sea Res. Part II Top Stud Oceanogr, 49, 4145-4161, 2002.

Sasse, T. P., McNeil, B. I., and Abramowitz, G.: A novel method for diagnosing seasonal to inter-annual surface ocean carbon dynamics from bottle data using neural networks, Biogeosciences, 10, 4319-4340, doi:10.5194/bg-10-4319-2013, 2013.

Schneider, A., Wallace, D. W. R., and Körtzinger, A.: Alkalinity of the Mediterranean Sea, Geophys. Res. Lett., 34, L15608, doi:10.1029/2010jc006171, 2007.

Schneider, A., Tanhua, T., Körtzinger, A., and Wallace, D. W. R.: High anthropogenic carbon content in the 
Eastern Mediterranean, J. Geophys. Res., 115, C12050, doi:10.1029/2006g1028842, 2010.

Schneider, B. and Roether, W.: Meteor 06MT20011018 cruise data from the 2001 cruises, CARINA Data Set, available at: http://cdiac.ornl.gov/ftp/oceans/CARINA/Meteor/06MT512/ (last access: 11 December 2015), Carbon Dioxide Information Analysis Center, Oak Ridge National Laboratory, US Department of Energy, Oak Ridge, Tennessee, doi:10.3334/CDIAC/otg.CARINA06MT20011018, 2007.

Souvermezoglou, E., Krasakopoulou, E., and Goyet, C.: Total inorganic carbon and total alkalinity distribution in the Aegean Sea, CIESM, 312 pp., 2010.

Stone, M.: Cross validatory choice and assessment of statistical predictions, J. R. Stat. Soc. B-Stat. Methodol., 36, 111-147, 1974.

Takahashi, T., Olafsson, J., Goddard, J. G., Chipman, D. W., and Sutherland, S. C.: Seasonal variation of $\mathrm{CO}_{2}$ and nutrients in the high-latitude surface oceans: A comparative study, Global Biogeochem. Cy., 7, 843-878, 1993.

Takahashi, T., Sutherland, S. C., Wanninkhof, R., Sweeney, C., Feely, R. A., Chipman, D. W., Hales, B., Friederich, G., Chavez, F., Sabine, C., Watson, A., Bakker, D. C. E., Schuster, U., Metzl, N., Yoshikawa-Inoue, H., Ishii, M., Midorikawa, T., Nojiri, Y., Körtzinger, A., Steinhoff, T., Hoppema, M., Olafsson, J., Arnarson, T. S., Tilbrook, B., Johannessen, T., Olsen, A., Bellerby, R., Wong, C. S., Delille, B., Bates, N. R., and de Baar, H. J. W.: Climatological mean and decadal change in surface ocean $\mathrm{pCO}_{2}$, and net sea-air $\mathrm{CO}_{2}$ flux over the global oceans, Deep Sea Res. Part II Top Stud. Oceanogr., 56, 554-577, 2009.

Takahashi, T., Sutherland, S. C., Chipman, D. W., Goddard, J. G., Ho, C., Newberger, T., Sweeney, C., and Munro, D. R.: Climatological distributions of $\mathrm{pH}, \mathrm{pCO}_{2}$, total $\mathrm{CO}_{2}$, alkalinity, and $\mathrm{CaCO}_{3}$ saturation in the global surface ocean, and temporal changes at selected locations, Mar. Chem., 164, 95-125, 2014.

Tanhua, T., Alvarez, M., and Mintrop, L.: Carbon dioxide, hydrographic, and chemical data obtained during the R/V Meteor MT84_3 Mediterranean Sea cruise (5-28 April 2011), available at: http://cdiac.ornl.gov/ftp/oceans/CLIVAR/Met_84_ 3_Med_Sea/ (last access: 20 August 2015), Carbon Dioxide Information Analysis Center, Oak Ridge National Laboratory, US Department of Energy, Oak Ridge, Tennessee, doi:10.3334/CDIAC/OTG.CLIVAR_06MT20110405, 2012.
Touratier, F. and Goyet, C.: Decadal evolution of anthropogenic $\mathrm{CO}_{2}$ in the northwestern Mediterranean Sea from the mid-1990s to the mid-2000s, Deep Sea Res. Part I Oceanogr. Res. Pap., 56, 1708-1716, 2009.

Touratier, F. and Goyet, C.: Impact of the Eastern Mediterranean Transient on the distribution of anthropogenic $\mathrm{CO}_{2}$ and first estimate of acidification for the Mediterranean Sea, Deep Sea Res. Part I Oceanogr. Res. Pap., 58, 1-15, 2011.

Touratier, F., Guglielmi, V., Goyet, C., Prieur, L., Pujo-Pay, M., Conan, P., and Falco, C.: Distributions of the carbonate system properties, anthropogenic $\mathrm{CO}_{2}$, and acidification during the 2008 BOUM cruise (Mediterranean Sea), Biogeosciences Discuss., 9, 2709-2753, doi:10.5194/bgd-9-2709-2012, 2012.

Wanninkhof, R., Park, G. H., Takahashi, T., Sweeney, C., Feely, R., Nojiri, Y., Gruber, N., Doney, S. C., McKinley, G. A., Lenton, A., Le Quéré, C., Heinze, C., Schwinger, J., Graven, H., and Khatiwala, S.: Global ocean carbon uptake: magnitude, variability and trends, Biogeosciences, 10, 1983-2000, doi:10.5194/bg10-1983-2013, 2013.

Watson, A. and Orr, J.: Carbon Dioxide Fluxes in the Global Ocean. In: Ocean Biogeochemistry, edited by: Fasham, M. R., Global Change - The IGBP Series (closed), Springer Berlin Heidelberg, 123-143, 2003.

Zweng, M. M., Reagan, J. R., Antonov, J. I., Locarnini, R. A., Mishonov, A. V., Boyer, T. P., Garcia, H. E., Baranova, O. K., Johnson, D. R., Seidov, D., and Biddle, M. M.: World Ocean Atlas 2013, Volume 2: Salinity, edited by: Levitus, S., and Mishonov, A., NOAA Atlas NESDIS 74, 39 pp., 2013. 